\title{
The right of thirst: water as a human right and as a commons
}

\begin{abstract}
Koumparou D.* Received: 17/12/2017, Accepted: 7/7/2018, Available online: 26/9/2018 https://doi.org/10.30955/gnj.002551

Abstract

Water is not only a vital natural resource but is also a social symbol that makes it a 'total social fact'. 'Hydroschizophrenia' is a term that characterizes the present condition of the status of water and reflects a disconnection between water and society. Liberal environmentalism considers the environment as an economic good. The privatization of water invokes a wide range of reactions, social movements and protests. The primary concepts that underlie the movement against the privatization are the human right to water and water as a commons. These concepts are traced to the idea of the ancient 'right of thirst'.
\end{abstract}

Laboratory of Technology and Policy of Energy and Environment, Hellenic Open University, Parodos Aristotelous 18, 26335, Patra, Greece

*to whom all correspondence should be addressed: e-mail: dkoumpa14@gmail.com

Keywords: commons, human right to water, hydroschizophrenia, right of thirst, total social fact, water

\section{Introduction}

The Greek philosopher Thales of Miletus (600 BC) stated, 'Water is the beginning of all'. Water is a vital element for every living organism. In water science, this resource has been studied and treated according to predefined uses, such as irrigation or urban water supply and sanitation, and has been detached from its social context, causing its ability to shape social, political, and economic relationships in societies, from the local to the global scale, to be overlooked.

For social sciences, water is also the beginning of all. Water is not only a physical resource but also a cultural, social, political and economic resource. Water is a cultural resource because water is often a component of religious rituals and everyday life rituals. Water is social because it captures the intertwined nature of the relationships among individuals, groups and institutions. Water is characterized as political because its property status and allocation are determined by the ruling political system (Salzman, 2005). The economic function of water is its most well-known characteristic.

Social science fields interested in the various dimensions of water analyse its multiple facets and apply a variety of theoretical backgrounds to offer a panoramic picture of water. Geographers (Barnes \& Alatout 2012) have developed the terms 'hybridity' and 'hydrosocial cycle' to highlight the links between water's material and symbolic dimensions and to highlight the uneven patterns of access to water. Environmental historians have demonstrated how water bodies such as rivers or lakes are not fixed but or both (Cioc, 2002; White, 1998). Anthropologists elucidate the position of water within the social, cultural, spiritual, and political dimensions of a society (Kaplan, 2011; Orlove, 2009; Strang, 2010).

Mosse (2008) considers the relationship between society sociological, and regional dimensions. Salzman (2005) reveals that these facets of water are extremely complex and interrelated. Water's characteristics are more complicated with respect to drinking water. Social organizations and groups have different beliefs, thoughts and attitudes towards water, and culture influences how water is perceived. The societal ethic toward water reflects the conceptions and expectations not only for water but also for the environment on a broader level and, more importantly, for the society itself. When an imbalance exists in an ethical system and the moral rightness of an action is determined by the perspectives and norms of a society, then social upheaval occurs and social pressure for a new re-arrangement increases.

This study adopts Marcell Mauss's (1990) definition of 'total social fact' and applies this term to water. Orlove and Caton (2010) proposed this consideration of water and studied its sustainability. According to Mauss (1990), total social fact refers to a social phenomenon that intersects with all the domains of a society. When considering the various institutions and informal associations for water governance and allocation and how these act and are interrelated in the water sector, then, beyond doubt, water is a total social fact. When approached from an interdisciplinary perspective, knowledge and information regarding water issues indicate its totality.

Another term that draws strong parallels with the 'total social fact' is 'Waterworld', which was introduced by Hastrup (2009). This term was developed to capture all the types of connections that water creates within a society, perceptions regarding its use, its value in a given social and economic system and its technological context.

Under the weight of the total social fact, this author seeks to document and analyse the nature of world voices that are proponents for the human right to water and water as are shaped by the needs of humanity, the power of nature, and water as a complex problem with historical, 
a commons. Although the concepts of human rights and commons have been extensively analysed, a combination of these two concepts that considers social pressures and the demand for water has not been analysed in depth (Murthy, 2013; United Nations, 2013; Zetland, 2011). This study proposes that their amalgamation was established by the 'the right of thirst' in ancient times.

These two concepts appear to be an antidote to problems related to water, including its organization, governance, allocation, and numerous interrelated components that provide evidence that water is a total social fact. For most social movements about water in the West, East, North and South, 'human right' and 'commons' are popular catchphrases that are used as primary 'response' to water privatization. This study argues that the social demand for access to water without exclusions is a restatement of the ancient 'right of thirst'. According to this right, water is prescribed as a commons, and no individual who asks for water can be deprived of it, for any reason: it must be made available to everyone.

The concept of the 'right of thirst' was first described in Jewish Law (Salzman, 2005; Zetland, 2011) and combines two contemporary principles: (i) water as a human right, where all humans have access to water and no individual can be denied water, and (ii) water as a commons, where a local community that depends on a body of water controls and regulates the access to water and its allocation. The 'right of thirst' could be considered a historical argument that emphasizes the role of local communities and specifies a demand for the (re-) municipalization of water, against neoliberal practices that favour the privatization of water. The right of thirst suggests that all individuals should have access to water, without discrimination, and water management should be exercised according to principles that are established by its users or consumers.

What today seems ground-breaking and socially fair was also relevant in the past when social systems were trying to ensure the survival of their members through 'the right of thirst'. The 'human right to water' and 'water is a commons' are consolidated in 'the right of thirst'.

This study proposes that community-based water management that promotes water access and allocation that is socially inspired, which is what is demanded today by social movements against the privatization of the water, refer to what the 'right of thirst' declares and promotes. Water is not only a natural resource; global social movements have transformed it to a symbol of democracy and social justice.

The remainder of this paper first tries to study and to comprehend the ancient right of thirst. In the following section the adoption of human right to water and its dynamic is examined. This is followed by the theoretical assumptions of the water as a commons and the role of community in water management. Then, results and discussion about the main findings, their considerations and their implications are developed. Finally, the factual elements of drinking water governance today are presented.

\section{The right of thirst}

Throughout human history, the access to safe and clean water has been one of the primary collective social concerns. It is self-evident that drinking water was the utmost concern. In Jordan, archaeological excavations found water storage sites dating from 4000 BC (Salzman, 2005); the same is true in the Maya Lowlands from the period of 250-900 AD (Scarborough \& Gallopin, 1991). On the island of Crete, in Greece, a large distribution system transferred water from relatively large distances to the Knossos Palace from 3500 to 1200 BC. Because of Eupalinean digging on the island of Samos, in Greece, water was transferred from one side of the island to the other to satisfy the residents' thirst. During the golden era of democracy in Athens, to address intensive water scarcity, water was supplied primarily by wells that were constructed as public and private projects (Koutsoyannis, Zarkadoulas, \&Tchobanoglous, 2008.).

The first water management plans were principally established for the satisfaction of thirst. Access to drinking water has been a social priority throughout centuries and millennia. In religious systems, water has relevance, and specific scriptural passages are dedicated to water. According to Salzman (2005), in traditional Jewish Water Law, water was considered a common property resource and not a free access resource. Priority was determined by resource's appropriators, according to the use. Water accommodated the needs of the community and no one lacked drinking water was turned away. This refers to the 'right of thirst' as recorded in Jewish Law. Sharia, the Islamic law, is defined verbatim as the 'way to water'. Furthermore, 'the right of thirst' in Jewish Law expands in Islamic law beyond humans to animals. In Islam, no distinction is made between humans and nature or between society and natural resources. In both religious systems, water is a gift from God to all people and all living organisms; sharing water is a blessed obligation (Salzman, 2005; Zetland, 2011).

The property status of water is a main concern for political and religious systems (as social constructions) regarding the regulation of the access to water. A community of users was responsible for developing a plan of access, allocation and use. In religious writings, the property status of water is revealed. Certain scholars purport that rules regarding the access to water preceded rules regarding land ownership (Zetland, 2011).

The right of thirst, as explained by Salzman (2005), was adopted later by the Roman Empire, which provided free drinking water to its subjects. In the name of Caesar (as God again), it was ensured that all citizens of Rome had access to drinking water. Water was a public good and everyone had access to it, but this access nevertheless revealed a social hierarchy. The poor carried water from public basins in the streets and the rich had water in their homes (Salzman, 2005).

This type of water management, which recognizes the right of thirst, was repeated centuries later in the cities of New York and London. During the eighteenth and nineteenth 
centuries, the first attempts at water privatization had taken place in both cities, but they were unsuccessful. Both cases indicated that the privatization of water could not offer even the most basic services and did not meet the basic needs of drinking water. After a disaster in New York City and social turmoil in London, water became a public service again (Salzman, 2005; Wilk, 2006).

Trentmann and Taylor (2005) noted that water wars in London contributed to the emergence of the consumer culture. Water users were turned, for the first time, into consumers-persons who devoured water, gas and food. A fundamental difference from the present is that water was a taxed consumable, not a commodity.

For that era of London, the political aspect of water consumption related to the concepts and notions of property, social accountability, representation, and public service. These dimensions of consumption are not always included in the contemporary use of the term 'water consumption'. The present-day consumption of potable water, particularly if we consider bottled water, is a commercial good and luxury, where design, desire and brands have a prominent role (Trentmann \& Taylor, 2005). In a world that is confronted with climate change, the use of bottled water is irrational because vast amounts of energy, materials and water are wasted for its production and transportation to be sold in places where cheap, clean, and safe water are readily available. Ironically, the same countries that consume bottled water are seeking solutions to the problem of the disposal of plastics that litter their land and ocean.

'The right of thirst', at first reading, has a complex meaning. For example, some have questioned why it is called 'the right of thirst' and not the 'right to water'. The latter appears to be more correct and appropriate. The 'right' declares that every living creature can become thirsty. The 'right of thirst' implies the right of all living organisms to drink water to satisfy their physical needs. This is an unambiguous fact and there is no need for further analysis or justification. Gandy (2004) stated, '....water is essential in maintaining the metabolism, not only of the human body, but also of the wider social fabric...'. This right implies that society has an obligation to offer water to all creatures to meet their basic need, thirst. This right is a common, collective and societal moral obligation towards Nature and Life. This obligation is transformed into a strategy for the appropriation and management of water resources, and this, in turn, is the mode by which the society itself is structured.

\section{The human right to water}

In 2010, the United Nations (UN General Assembly with Resolution 64/292) unambiguously recognized the human right to water, coupled with the need for sanitation. This was the first time that clean drinking water and sanitation were recognized as necessities and officially recognized, not only for meeting the basic needs for survival but also for the realization of human rights. The right to clean drinking water is essential for life and dignity but also contributes to wealth and other human rights, including the right to health and the right to development.

Regarding developing countries, the Millennium Declaration of 2000 provided an international agenda for security, development, human rights, and the environment. The basic objective of this declaration was to articulate specific development goals related to poverty, water and education and to make tangible commitments to promote democracy and respect for all human rights, including the right to development and relevant economic, social and cultural rights, with a particular focus on the rights of vulnerable groups such as minorities, women and migrants (Scanlon, Cassar, \& Nemes, 2004). In this context, not only the materiality of water as a natural element but also its social, cultural and economic dimensions were recognized (United Nations, 2013).

If we agree that the recognition of the human right to water highlights the social and cultural dimensions of the water, then beyond human rights there are cultural rights. The difference between human and cultural rights is that the former applies to individuals and the latter applies to identifiable groups. Cultural rights are occasionally neglected because they are not codified and their realization relies on the same mechanisms that create them: pressure, public relations, and politics (Kottak, 1999).

In 2011, the United Nations Human Rights Council passed a new Resolution that asks States to ensure sufficient financing for sustainable delivery of water and sanitation services (United Nations, 2014). In the same year, the World Health Organization (WHO) asked its Member and national hygiene services 'to ensure that national health strategies contribute to the realization of water- and sanitation-related Millennium Development Goals while coming in support to the progressive realization of the human right to water and sanitation' (WHO, 2014).

Because of these official requests, Governments are obliged to introduce strategies and measures regarding water rights and respect. States and/or governments should use their authority to create suitable conditions. However, the resolution does not prescribe methods, tools or principles of implementation, such as citizen participation in decision making processes, transparency assurance, or social accountability.

Reading between the lines, the concept of human rights abrogates the unrestrained function of the nation-state by shaping social, political, and cultural life, including the concepts of distributive justice and morality. Human rights can be perceived as inalienable (nation-states cannot abridge or terminate them) and meta-political (superior to individual nation-states) (Kottak, 1999). This approach is one version of globalization, where a very strong interconnection exists between political and economic institutions. Schmidt and Mitchell (2014) support this argument and note that human rights have meaning for a given social system within its political dimensions and powers and are 'the products of a particular moment and place' (Kennedy, 2002). 
The concept of human rights contests the power of the nation-state or other forms of collectivity or co-operation. This is the neoliberal version of human rights. Human rights imply that individuals are unique self-governed entities that may pursue their happiness in a manner that is antagonistic toward collective or communal rights or may not be compatible with them (Schmidt \& Mitchell, 2014). Individuals strive to increase the value and strength of their competitive position relative to others. Consequently, there is no interest in a collective or common scope or good and no expectation to collectively establish power for a social group or a community (Brown, 2015).

Conversely, Murthy (2013) supports that a characterization of water as a human right is an antiphon to global economic trends that increasingly emphasize the virtues of the efficiency, financial sustainability, and privatization of water resources, management and services. This same author purports that a human right is a vehicle for communities and social groups to resist inequities and injustice in accessing and managing water resources. Human rights refer to standards of justice and morality that supersede country, political association, religion and culture. Murthy (2013) enhances this argument and notes that several countries, including Canada and the US, favour water privatization because of their politics and do not recognize the right to water; consequently, it took months to rebut this mindset and ultimately reach a consensual decision in the intergovernmental organization of the United Nations.

Bakker (2007) reinforces the latter argument by noting that prior to the recognition of the right to water, the supporting campaign was launched by anti-water privatization proponents. The recognition of the human right to water implies that water is a political priority similar to poverty, food, and health. This right to water also empowers citizens to demand that the state meet their basic needs (Bakker, 2007). Later, the campaign for water as a human right was adopted by water industry representatives, was reported on industry websites and even by the Davos World Economic Forum in 2004, which indicates the prevalence of neoliberalism.

Nonetheless, very often, criticism of the human right to water is pervaded by the concepts of anthropocentrism and ecocentrism (Bakker, 2007). In regards to anthropocentrism, the attention is on human needs and ignores the needs of the eco-system in which humans are imbedded. Water should exclusively meet human needs. The right of thirst offers a different perspective and is intimately connected to Nature; humans are a part of Nature and not the Master of it-the role of the Master belongs to God or to the Emperor.

Ecocentrism focuses on the capitalist system. From this perspective, the private sector is compatible with human rights, and as an outcome, a liberal or neoliberal economy does not oppose human rights. Partnerships-for construction, operation and management of water services in cooperation with private companies-in the water sector are formed, as in other utility sectors, such as the energy sector. The collapse of Enron, which by the late 1990s had become one of the largest water multinationals, cast doubt on the overall suitability of the private sector (Bakker, 2007).

As the story unfolds, the recognition of the human right to water does not always result in tangible changes regarding water issues, and 'water wars' continue, driven by the political, social and economic implications of water and its strategic role. The human right to water does not ensure that everyone has access to water. The method used to implement this right in practice, presupposes that someone must pay for it.

The human right to water creates a system of commitments and agreements. First, this right postulates that there is adequate, safe water over time and that water resources have a sustainable capacity to meet all the needs for well-being, prosperity and development. It is a matter of perspective if the human right refers to the water resource or the water infrastructure developed under technological, social, demographical, economic, environmental, cultural, and legal conditions or to both of these. In our era of sophisticated scientific advances in water science, including the multitude of tools or techniques and equipment for water systems, the question that must be answered is- not how to bring water to 2 billion individuals in certain geographical areas, who are deprived of water, but rather why certain social groups all over the world (in the west and elsewhere) do not have access to water. Water is an issue that primarily affects poor citizens in the developed and developing world, creating the social phenomenon of water poverty. For example, the 'water poor' citizens of France, the UK (WHO, 2014; Zetland, 2011), and Greece in the last 8 years, which has been affected by strict austerity measures, cannot afford to pay bills to water companies.

Given the sovereignty of the Washington Consensus, governments must acknowledge human rights and grant the authority to private companies. In the water sector, this practice is widespread. In the developing world, private companies are engaged in resource exploitation and in the developed world, state infrastructures re-allocate water as a product among consumers or they sell it like other industrial products, separated from its social life. Poor individuals are downplayed or even excluded. Occasionally communities are excluded, but often they raise their voice and engage in water wars, fighting for their rights and occasionally they win. The financialization of water leads to a mismatch between the needs of society and the priority of the private sector to maximize profits (Bayliss, 2014) and results in a disconnect of society and water, what I refer to as 'hydroschizophrenia'.

'Hydroschizophrenia' may be the correct term to explain the current state of affairs regarding water and its management throughout the world. This term was introduced by Llamas in 1975 to describe the creation of separate surface water and groundwater governance and policies, despite the recognition of the hydraulic connection between these two water resources. We use this term to describe the global status of water governance and policy, today. 
'Hydroschizophrenia' describes the separation between water and society and ignores their intense nexus. (Koumparou, 2018). Water, as perceived by neoliberalism, is a consumable good, a product that is sold and bought in different packages and for various prices and is deprived of all other attributes. Its societal dimension is ignored. Furthermore, satisfaction of the need for water, is dependent on decisions that are made behind closed doors, in government offices or in executive boardrooms, without the participation of users or consumers.

\section{Who owns the water that quenches the thirst: the water as a commons}

Activists and social movements that oppose the privatization demand that water be treated as a commons. Increasingly, the voices raised against the privatization of water and in favour of water as a commons are intensified.

In prior studies regarding environmental policy, concepts such as commons, common property, or community property were perhaps the most misunderstood. Reports were made regarding common property resources that assume this terminology is universally accepted without variations. It is crucial to clarify the categories of ownership, of property, and then develop a theory or a policy for the management of the resource.

Property refers to a claim on the resource and its services and the right to property is a claim on the benefits that arise from the availability and intensity of the use of the resource (Gibbs \& Bromley, 1989). Property regimes are human constructs that play an important role in how societies are organized and develop their characteristics as a result of what is considered rare and what is considered valuable. Property is a tool for the organization of society and is a social institution; specific ownership regimes are selected for specific social purposes (Bromley, 1992; Hanna \& Munasinghe, 1995; Hawkins, 1992).

In the Universal Declaration of Human Rights, the right to own property is specified, but not the right to the property. Zetland (2011) notes that property rights differ from human rights. Governments provide human rights and protect both types of rights. Furthermore, property rights can be abolished, but human rights cannot.

Ostrom's work (1977; 1987; 1990; 1992) reveals how societies have contrived diverse institutional provisions for the management of commons and avoided destruction or tragedy. Her scholarship emphasizes how societies develop an appropriation system for these resources. The system's efficacious function serves certain principles. For stable commons effective communication, internal trust, reciprocity and the nature of the resource system itself are crucial factors. In prior studies regarding commons, a network of social relationships is developed between the inner users of a community and the institutions and/or entities that are outside of the community (McCay, 1987; McCay \& Acheson, 1987; Taylor, 1992). The 'tragedy of the commons' (Hardin, 1968) is a sophisticated presentation of the problem of mutual cooperation that describes the advantages of short-term selfishness, or self-interest, in contrast to the need for long-term cooperation and collective outcomes.

Commons are distinguished from other forms of organization and government because they belong to users. These resources are not open access, as the dominant notion in the past considered them to be. Commons are governed by rules that define who has access to the resource and its services. The decisions and arrangements are made inside the community of the users rather than by external control systems, mechanisms or agents. The resource is not a pool that any member of the community can use according to his or her own interests and for personal benefits only. Commons rely on certain democratic and egalitarian principles (Bromley, 1992; Ciriacy - Wantrup \& Bishop, 1975; Demsetz, 1967). This is the primary difference from privatization, which promises only effectiveness.

The creation of an organization or a community for water management as a commons does not guarantee that this organization will survive over time. Cooperation, mutual trust, and communication among members, are transformed over time. Individuals who adhere to the rules of commons often must decide if they will renovate their institution and in which direction, to better adapt to specific environmental, social and economic conditions. Adaptation to a new situation is a difficult process and often, a foreign intervention is necessary. However, change should be conducted in a manner that will not alter the basic merits, ethos and beliefs of the community. Commons not only operate between society and resources but also between society and individuals. The social roles and obligations are determined according to participation in a community, which highlights the primary difference between a community system and an industrialized system that operates with salaried workers, a hierarchical organization, and for the pursuit of profit.

Commons cannot emerge if there is not a basic form of organization and a set of simple rules that restrict the desires, interests and actions of individuals (Feeny, Berkes, McCay, \& Acheson, 1990; Ostrom, 1990). The nature of the property status and the determination of the rights are defined by the members of a community, who are restricted by the rules and conditions that exist rather than the resource itself (Gibbs \&Bromley, 1989). Water as a commons implies that its governance is effective with limited or no conflicts and little effort is applied by users to comply with the rules. Progressive changes due to new techniques and innovation are incorporated to enhance effectiveness. When a risk or threat is present, this scheme should be able to overcome the challenge (Gibbs \& Bromley, 1989). A direct relationship exists between the property rights structure and the ability of individuals to impose costs on others.

Commons are the best-known examples of community ownership, particularly for a water resource that is used for irrigation. Bakker notes (2008) that the concept of community is extremely ambiguous, particularly in regard to urban water systems. Bakker (2008) studied the community as an alternative to privatization and 
developed a typology that distinguishes the water supply system as a resource, its ownership, and its governance. For urban water, the community primarily is concerned with the infrastructure; re-municipalisation represents the typically favoured management system. The trend towards re-municipalisation becomes more pronounced as the privatization of the water service in Europe collapses. Despite the disappointing results in water services in England, France and Germany, and the US, water privatization is a highly intensive desideratum for certain European countries and particularly for European countries, in South, that face or faced economic problems and the implementation of austerity measures by a Memorandum that was designed by the European Commission, the European Central Bank and the International Monetary Fund. For example, in Greece, more than one level of government or authority is involved in water planning, management, and delivery. These levels include the municipal government, regional and national agencies, and the Memorandum. Under the Memorandum governance, the owner of water should be a private company and not the municipality as in the past. And then a 'water war' begun in Greece.

If we consider that neoliberalism is a constantly changing combination of ideas and practices that emerge in various ways, in different places, and intersect with other modes of governance and historical contexts, then even the concept of commons can be misconstrued, such as human's right to water (Brown, 2015). From the perspective of neoliberalism, commons may be perceived as the sum of private property rights to a resource. This association can act as an economic entity in accordance with the market rules. However, the sense of commons entails, at its core, collectivity, reciprocity and sharing, and not the sum of individual interests and profits.

From the perspective of neoliberalism, the role of the community is not new and has gained its position, in the context of decentralization that was popular in the 1980s, for different reasons in Africa and Latin America and in western states. In all contexts, decentralization beyond an administrative tool is a political process that is designed for bottom-up decisions. Decentralization results in the process of devolution, which offers more autonomy to communities on almost all fiscal and political levels. Privatization may be perceived as another type of decentralization (Agrawal \& Ostrom, 2001; Larson \& Soto, 2008). Neoliberalism embraces municipalities under the umbrella of decentralization and transforms them into profit-oriented companies according to free market standards, ignoring the local context, cultures and concerns. From this perspective, decentralization has emerged because of both conservative and progressive factors, both in neoliberal and anti-neoliberal contexts and in all versions, similar to sustainable development (Larson, 2004) or the human right to water.

Urban water systems consist of different perceptions about allocation, political power, and groups with different orientations, theories, priorities and interests, that exercise the management. The governance of water is a challenge, and its organization is very difficult endeavour and the involvement of civil society is (or should be) a component of a fair water governance plan.

\section{Results and discussion}

The notion of profiting from the access and allocation of a vital resource, such as water, results in political battles and ethical dilemmas. For the past 30 years, the introduction of neoliberal economic theories and philosophy have been powerful, and the privatization of water has become a political issue. From the perspective of neoliberalism, profit maximization is the primary issue and can be achieved through privatization. Different cultural conditions or cultural spheres do not affect the individualistic behaviour embedded in our every action. The marketized forms of all products, goods and services are a necessity worldwide to enhance development and sustainability (McDonald \& Ruiters, 2012). Neoliberalism, environmental changes and environmental politics are interwoven and, in turn, form the social structure and net.

The 'human right to water' and 'the water as a commons' are the most powerful arguments against water privatization. Water as a human right highlights, first, that everyone should have access to water without discrimination or exclusion. Commons and communities represent a vision for solidarity, democracy on the ground, and justice. Commons are created and operated by communities to address certain problems and provide alternative, non-commodified agents that meet social and environmental needs. Common implies access to a vital resource without the mediation of the free market and is designed to serve the appropriators' needs.

These two premises against the privatization of water reiterate the ancient 'right of thirst'. This right was recognized long before the ego-driven economy and society existed and even before human rights were invented; it is a right that cannot be considered as ecocentric or anthropocentric. Conversely, this right could be characterized as sociogenic, using Harvey's term (2012). Concepts such as these integrate the need for a rearrangement of society and re-definition of the relationships within it. Until now, the role of the state in this political and economic context is to enforce the processes of the privatization and commodification of water by neglecting or even by repressing any opposing movements (Harvey, 2005; McCarthy \& Prudham, 2004). This process occurs with respect to the human right to water globally.

The discussion regarding decentralization and commons initiates a dialogue about concepts like good governance and democracy on the ground, social justice, development and poverty alleviation, social justice, the role of citizens, local horizon, cultural landscape.

This discussion has been empowered by the unsuccessful and even catastrophic results of the privatization of public water services over the past 15 years. 'A quiet citizen revolution', as Kishimoto, Lobina, and Petitjean (2015) call it, is proliferating, and communities are demanding the control of water resources and services and its 
management in a manner that assures safety, guarantees access for everyone, limits conflicts, protects water resources and achieves sustainability. The principles of community management 'have become a central metaphor for ecological policy' (Willis, 2012) and provide methods that organizations and administrative bodies can use to incorporate community ethics, culture and vision.

To retain its power and to perpetuate itself, neoliberalism attempts to reconcile these stresses and integrates components of these movements. Decentralization and the constantly growing power of Municipal Authorities follow the old pattern of capitalistic survival. Municipalities now must develop their profit oriented business plan. De Angelis (2003) purports that today, neoliberalism needs help from the commons too for its survival and concurrently, commons create social structures that are grounded in social justice and democracy. A gridlock of our time is that water is a symbol and a vital element for democracy, justice, and is no longer only a resource for meeting the instinct of thirst and achieving economic growth and individualistic prosperity. According to Appadurai (1986), the distribution of water produces interdependence among members. The social and political relationships developed by water prejudge the function of the natural resource but also identify interesting qualities of social life.

Geertz (1972) mentions that water brings into play different forms of power within societies. To clarify, water can legitimize certain groups over others. The power over water resources and infrastructure is an exercised authority by corporations or states over people or states. Water is used as a weapon, depriving life. This is currently occurring in Syria and has been occurring in Palestine for decades.

These aspects, perspectives and approaches to water, to its meaning and to its political, social and economic dimensions and all the symbolism that it implies, make water a 'total social fact'. Different domains and institutions are not connected to each other in a random manner, but in a systematic and intensive manner. Water is a total social fact that has the ability to compose and connect sectors and institutions that seem to have no connections. For example, the water supply from a source depends on physical infrastructure and entails legal and political systems and a wide range of bureaucracy from local to national or even more so for an international governance structure. Economic systems, technology, education, and tax services are other factors that define water sourcing, its treatment, distribution, management, use, and allocation.

A total social fact implies that the fundamental and established functions of a social organization are linked to each other and resembling the construction of a hybrid situation. The facts may individually seem contradictable and yet, they are collectively coherent and tightly interlinked (Kasuga, 2011). The intertwined nature of the total social fact does not imply that economic activities and relationships are an integrated segment of the social system. On the contrary, they should first be examined apropos of all other elements of social totality to understand how the economic aspirations of a society are formulated, then coherently integrated into the legal, political, social and cultural context. Mauss (1990) indicated that social relationships are the prerequisites of an economy and engaging in a socially ethical system. Social phenomena have the most heteroclite compatibilities.

The approach to water as a 'total social fact' raises delicate issues similar to those raised by 'the right of thirst', including property status, ethical systems, modes of production, social justice, and democracy.

Opponents to privatization demand the recognition of 'the right of thirst' and a re-connection of water with society. The bridging of this gap between water and society as a treatment for hydroschizophrenia requires a new rearrangement of social systems. In this process, with the capital to become increasingly more cosmopolitan, a social protest against privatization can establish a social imaginary (Morgan, 2004) for cosmopolitan hydraulic citizenship (Anand, 2001) and multinational solidarity and cooperation.

\section{Conclusions}

Without water there is no life. This declaration inevitably leads to the finding that whoever controls the water, controls life, controls society from local to the global scale. This makes water a 'total social fact'.

Water has been treated as a commons throughout the centuries, from ancient times, as a right of thirst. Today it is regarded as a commodity according to the neoliberal narrative, through a centralized or decentralized process, leading to the status of hydroschizophrenia. Voices from all over the world, call for democracy and social justice.

Because of multifaceted nature of the water a link between ethics and politics, society and nature, is the prerequisite for the advent of a sustainable world and clean and safe water to all, without discrimination as a 'right of thirst' and as a commons, requires to go beyond the binary system such as rights versus markets, public versus private. Drinking water is a fundamental complex resource to manage, and reaching the balance among its many natures is a difficult endeavor.

\section{References}

Agrawal A., \& Ostrom, E. (2001), Collective action, property rights, and decentralization in resource use in India and Nepal, Politics and Society, 29, 485-514.

Anand N. (2011), The Social Life of Water in Mumbai, Doctoral Dissertation, Stanford University.2011.

Appadurai A. (1986), The Social Life of Things. Commodity in Cultural Perspective, Cambridge University Press.

Bakker K. (2007), 'The Commons' Versus the 'Commodity': Alterglobalization, Anti-privatisation and the Human Right to Water in the Global South, Antipode, 39, 430-455.

Bakker K. (2008), The ambiguity of community: Debating alternatives to private-sector provision of urban water supply, Water Alternatives, 1, 236-252. 
Barnes J. \& Alatout S. (2012), Water worlds: Introduction to the special issue of Social Studies of Science, Social Studies of Science, 42: 483-488.

Bayliss K. (2014),. The financialization of water, Review of Radical Political Economics, 46, 292-307.

Brown W. (2015), Interview to newspaper AVGH. Available at http://www.avgi.gr/article/6069144

Bromley D.W. (1992), The commons, property, and commonproperty regime, in: D.W. Bromley (Ed.), Making the Commons Work: Theory, Practice, and Policy, pp.3-15. Institute for Contemporary Studies, San Francisco.

Cioc M. (2002), The Rhine: An Eco-Biography, 1815-2000. University Washington Press, Seattle.

Ciriacy-Wantrup S.V. \& Bishop R.C. (1975), "Common Property" as a concept in natural resource policy, Natural Resources Journal, 15, 713-727.

De Angelis M. (2003), Reflections on alternatives, commons and communities or building a new world from the bottom up, The Commoner, 6, 1-14

Demsetz H. (1967), Toward a theory of property rights, American Economic Review, 57,347-359.

Feen, D., Berkes, F., McCay, B. J., \& Acheson, J.M. (1990), The tragedy of the commons twenty - two years later, Human Ecology, 18, 1-19.

Gandy M. (2004), Rethinking urban metabolism: water, space and the modern city. City, 8, 363-379.

Geetrz C. (1972), The wet and the dry: traditional irrigation in bali and Morocco, Human Ecology, 1, 34-39.

Gibbs C.J.N. \& Bromley D.W (1989), Institutional Arrangements of Rural Resources: Common Property Regimes. In: F. Berkes (Ed.), Common Property Resources, pp. 22-32. Belhaven Press, London.

Hanna S. \& Munasinghe M. (1995), An introduction to property rights in a social and ecological context, in: S. Hanna \& M. Munasinghe (Eds.), Property Rights in a Social and Ecological Context. Case Studies and Design Applications, pp. 3-11. The Beijer, International Institute of Ecological Economies and the World Bank, Washington.

Hardin G. (1968), The tragedy of the commons, Science, 162, $1243-1248$

Harvey D. (2005), A Brief History of Neoliberalism. Oxford University Press, New York.

Harvey M. (2012), Drinking-Water and drinking water: Trajectories of Provision and Consumption in the UK, Taiwan and Delhi, Working Paper 02, University of Essex, Centre for Research in Economic Sociology and Innovation (CRESI), Colchester, UK.

Hastrup K. (2009), Waterworlds: framing the question of social resilience, in: K. Hastrup (Ed.), The Question of Resilience: Social Responses to Climate Change, pp. 11-30, Royal Danish Academy of Sciences and Letters, Copenhagen.

Hawkins R.B. (1992), Foreword, in: D.W. Bromley (Ed.), Making the Commons Work: Theory, Practice, and Policy, pp. xi-xii, California: ICS Press, San Francisco.

Kaplan M. (2011), Lonely Drinking Fountains and Comforting Coolers: Paradoxes of Water Value and Ironies of Water Use, Cultural Anthropology 26, 514-541.

Kasuga N. (2011), Total social fact: structuring, partially connecting, and reassembling, Revue du Mauss, 36, 101-110.
Kennedy D. (2002), The international human rights movement: Part of the problem?, Harvard Human Rights Journal, 15, 101125.

Kishimoto S., Lobina, E., \& Petitjean, O. (Eds.) (2015), Our Public Water Future: The Global Experience with Remunicipalisation, Public Services International Research Unit (PSIRU), Multinationals Observatory, Municipal Services Project (MSP) and the European Federation of Public Service Unions (EPSU),Transnational Institute (TNI), Amsterdam, London, Paris, Cape Town and Brussels.

Kottak C.P. (1999), The new ecological anthropology, American Anthropologist, 101, 23-35.

Koumparou D. (2018), The governance of the sociogenic climate change: perspectives and challenges, Review of Social Studies, 5, 25-43.

Koutsoyiannis D., Zarkadoulas N., Angelakis A.N., \& Tchobanoglous, G. (2008), Urban water management in Ancient Greece: legacies and lessons, Journal of Water Resources Planning and Management, 134, 45-53.

Larson A. (2004), Formal decentralisation and the imperative of decentralisation 'from below': a case study of natural resource management in Nicaragua, The European Journal of Development Research, 16, 55-70.

Larson A.M., \& Soto, F. (2008), Decentralisation of natural resource governance regimes, Annual Review of Environment and Resources, 33, 213-239.

Llamas M. (1975), Non-economic motivations in ground water use: Hydroschizophrenia, Ground Water, 13, 296-300.

Mauss M. (1990), The Gift: The Form and Reason for Exchange in Archaic Societies, Routledge, London.

McCarthy J. \& Prudham, S. (2004), Neoliberal nature and the nature of neolibaralism, Geoforum, 35, 275-283.

McCay B.J. (1987), Human ecology of the commons, in: B.J. McCay, and J.M. Acheson (Eds.), The Question of the Commons. The University of Arizona Press, Tucson.

McCay B.J, \& Acheson, J.M (Eds.) (1987), The Question of the Commons. The University of Arizona Press, Tucson.

McDonald D.A., \& Ruiters, G. (2012), Alternatives to privatization: Public options for essential services in the global South, Routledge.

Morgan B. (2004), Water: frontier markets and cosmopolitan activism, Journal of Politics and Culture, 27, 10-24.

Mosse D. (2008), Epilogue: the cultural politics of water: a comparative perspective, Journal of Southern African Studies, 34, 939-948.

Murthy S.L. (2013), The human right(s) to water and sanitation: history, meaning, and the controversy over-privatization, Berkeley Journal of International Law, 89.

Orlove B. (2009), Glacier retreat: reviewing the limits of adaptation to climate change, Environment, 51, 22-34.

Orlove B., \& Caton, S.C. (2010), Water sustainability: anthropological approaches and prospects, Annual Review of Anthropology, 39, 401-415.

Ostrom E. (1977), Collective action and the tragedy of the commons, in: G. Hardin \& J. Baden (Eds.), Managing the Commons, pp.173-181. W.H. Freeman and Company, San Francisco.

Ostrom E. (1987), Institutional arrangements for resolving the commons dilemma: some contending approaches, in: B.J. McCay, \& J.M. Acheson (Eds.), The Question of the Commons, pp. 250-265. The University of Arizona Press, Tucson. 
Ostrom E. (1990), Governing the Commons: The Evolution of Institutions for Collective Action. Cambridge University Press, Cambridge.

Ostrom E. (1992), The rudiments of a theory of the origins, survival, and performance of common property institutions, in: D.W. Bromley (Ed.), Making the Commons Work: Theory, Practice, and Policy, pp.293-318. Institute for Contemporary Studies, San Francisco.

Salzman J. (2005), Thirst: a short history of drinking water, Yale Journal of Law and the Humanities, 17, 92.

Scanlon J., Cassar, A., \& Nemes, N. (2004), Water as a Human Right?, IUCN, Gland, Switzerland and Cambridge, UK.

Scarborough V.L., \& Gallopin, G.G. (1991), A water storage adaptation in the maya lowlands, Science, 251, 658-62.

Schmidt J.J., \& Mitchell, K.R (2014), Property and the right to water: toward a non-liberal common, Review of Radical Political Economics, 46, 54-69.

Strang V. (2010), Water, culture and power: anthropological perspectives from 'down under', Institute of Advanced Study, 3, 14.

Taylor M. (1992), The economics and politics of property rights and common pool resources, Natural Resources Journal, 32, 633-648.

Trentmann F. and Taylor, V. (2005), From Users to Consumers: Water Politics in Nineteenth Century. Birkbecke Prints, London.

United Nations (2013), Report of the Special Rapporteur on the Human Right to Safe Drinking Water and Sanitation, Catarina de Albuquerque. Available at http://www.zaragoza.es/ contenidos/medioambiente/onu (accessed 25 June 2015)

United Nations (2014), International Decade for Action 'Water for Life' 2005-2015. Available at http://www.un.org/waterforlifedecade/human_right_to_wa ter.shtml (accessed 25 March 2015).

White G. (1998), Reflections on the 50-year international search for integrated water management, Water Policy, 1, 21-27.

World Health Organization-WHO (2014), Water Sanitation Health. Available http:://www.who.int/water_sanitation_health/highlights/w ha64_resolutions/en/ (accessed 20 March 2015).

Wilk R. (2006), Bottled Water: The pure commodity in the age of branding, Journal of Consumer Culture, 6, 303-325.

Willis P. (2012), Engaging communities: Ostrom's economic commons, social capital and public relations, Public Relations Review, 38, 116-122.

Zetland D. (2011), Water Rights and Human Rights: The Poor Will Not Need our Charity if We Need their Water. Available at http://ssrn.com/abstract=1549570 (accessed 20 September 2015). 